Research Article

\title{
Genotype $X$ Environment Interaction and Yield Stability in Early- Maturing Cowpea (Vigna unguiculata (L.) Walp.) Landraces in Ethiopia
}

\author{
Yirga Kindie $\mathbb{D}^{1},{ }^{1}$ Bulti Tesso, ${ }^{2}$ and Berhanu Amsalu ${ }^{3}$ \\ ${ }^{1}$ Sekota Dry Land Agricultural Research Center, Sekota, Ethiopia \\ ${ }^{2}$ Haramaya University, Dire Dawa, Ethiopia \\ ${ }^{3}$ Melkessa, Agricultural Research Center, Adama, Ethiopia \\ Correspondence should be addressed to Yirga Kindie; ykindie2007@gmail.com
}

Received 23 August 2021; Accepted 12 October 2021; Published 21 October 2021

Academic Editor: Amelia Salimonti

Copyright (c) 2021 Yirga Kindie et al. This is an open access article distributed under the Creative Commons Attribution License, which permits unrestricted use, distribution, and reproduction in any medium, provided the original work is properly cited.

The study was conducted to estimate the effects of genotype, environment, and genotype $\times$ environment interaction on grain yield and yield-related traits and to identify stability genotype. At six environments, twenty-four cowpea landraces and one check were evaluated in a $5 \times 5$ triple lattice during the 2019 cropping season. Data were collected on yield and yield-related traits. The analysis of variance for each environment and across environments showed significant differences among genotypes, environments, and GEI for most traits including yield. Environment, genotype, and GEI showed 27.45\%, 20.9\%, and 49.55\% contribution to the total sum of squares, respectively, for grain yield. This indicated that the environments were diverse and most of the variation in grain yield was caused due to interaction and environmental means. G24 (2632 kg ha $\left.{ }^{-1}\right)$ and G16 $\left(2290 \mathrm{~kg} \mathrm{ha}^{-1}\right)$ were the highest yielder and stable genotypes with mean grain yields above the grand mean $\left(2049.28 \mathrm{~kg} \mathrm{ha}^{-1}\right)$ and standard check $\left(2273 \mathrm{~kg} \mathrm{ha}{ }^{-1}\right)$. G24 and G16 were the most stable genotypes according to cultivar superiority, Wricke's ecovalence, regression coefficient, and devotion from regression stability models.

\section{Introduction}

Cowpea is an annual herbaceous and self-pollinated grain legume crop that belongs to family Fabaceae and genus Vigna. It is a diploid species with $2 \mathrm{n}=2 \mathrm{x}=22$ chromosomes [1]. The precise primary center of origin and the exact center of diversity of cowpea is not known, but according to OECD [2], Ethiopia is the primary center of diversity of cowpea and more than $66.5 \%$ of the arable land is very suitable for cowpea production.

Cowpea is drought resistant and adapted to marginal soil due to the nitrogen-fixing ability that makes it a useful staple crop for farmers in harsh environments under moisture stress and hot temperatures $[3,4]$. It is widely cultivated and consumed globally, especially in the arid and semiarid tropics and sub-Saharan Africa [5]. As documented by Abate et al. [6], about 38 million households (194 million people) grow cowpea in sub-Saharan Africa that accounts for about $84 \%$ of the world production. Particularly, production in Nigeria and Niger accounts for more than $45 \%$ and nearly $15 \%$ of the world's total production, respectively, with more than 4 million hectors of cultivated land each. Nigeria is supposed to be the highest producer of cowpea in the world with the production of 850,000 tons followed by Niger and Brazil, whereas Niger is the largest cowpea exporter in the world with an estimate of 215, 000 tons exported annually $[1,7]$. The crop is cultivated primarily for its edible seeds, young leaves (as a vegetable), pods seeds, soil improvement, and forage value $[8,9]$. Due to its fast growth habit, it covers the ground rapidly and, therefore, limits weed competition and soil erosion $[10,11]$.

In Ethiopia, cowpea is mostly produced in the Amhara region (North and South Wollo, Waghimra, and Oromia special zones), Tigray region, Oromia region (East Shewa 
and East and West Harerghe zones), Gambella (Anywaa Zone), and SNNPR: South Omo, Gamo Gofa, and Wolayta zones $[8,9]$. As documented by the aforementioned authors, Ethiopia has a great diversity of cowpea landraces (local farmers' varieties) in many traits and over $83 \%$ of cultivated cowpeas in Ethiopia are landraces. Cowpea production and utilization in Ethiopia is very low as compared to other African countries, though the country is claimed to be the center of diversity and/ or origin and has a high potential for the production of the crop.

Despite the fact that cowpea is a multipurpose grain legume, its productivity is very low and unstable across environments and years due to biotic factors (weeds, insects, and diseases), abiotic factors (soil type, altitude, rainfall distribution, and intensity), and scarcity of widely adaptable and early-maturing varieties $[12,13]$. The variability in environments such as location effect, seasonal fluctuation, and their interaction highly influences the production of cowpea in relation to yield potential $[14,15]$.

Genotype $\times$ environment interaction (GEI) is a challenge for plant breeders since it complicates variety recommendation because of the inconsistency of best-yielding genotypes across cropping environments and season. The effect of GEI is most commonly minimized by repeating the experiment at several sites in a single year, or over several crop seasons in a single site, or both $[16,17]$.

Even though there are many opportunities for breeders to develop cowpea varieties possessing different agronomic characteristics and inherent tolerance to a wide range of biotic and abiotic factors, progress of cowpea breeding in Ethiopia is very limited either in exploiting the available genetic variability in the country or from introduction of improved varieties. Moreover, information on the effect of genotype, environment, and their interaction and the performance stability of cowpea landraces is scanty. Therefore, evaluating cowpea landraces in contrasting environments to generate such information is imperative. In view of this, this research was initiated with the following objectives:

(i) To estimate the effects of genotype, environment, and genotype $\times$ environment interaction on grain yield and yield-related traits

(ii) To assess the stability of cowpea landraces for yield across environments

\section{Materials and Methods}

2.1. Description of the Study Area. The experiment was conducted at six cowpea-growing environments during the 2019 main cropping season in Ethiopia. The environments were as follows: Sekota, Kobo, Sirinka, Melkassa, Miesso, and Babile. The test environments were selected on the basis of representativeness for cowpea-producing environments. These six locations representing different agroecologies of cowpea-growing areas in Ethiopia and descriptions of the areas are presented in Table 1.

2.2. Experimental Materials and Design. Twenty-four Ethiopian cowpea landraces (Table 2) collected from the Amhara region, Tigray region, Oromia region, Gambella, and SNNPR were evaluated along with one check (released variety: Kanketi). The experiment was conducted using a $5 \times 5$ triple lattice design at each location, and each genotype was assigned randomly. The seeds were planted on the first week of July at a plot size of $4 \mathrm{~m} \times 2.4 \mathrm{~m}$ $\left(9.6 \mathrm{~m}^{2}\right)$ having four rows, with an interrow spacing of $60 \mathrm{~cm}$ and $20 \mathrm{~cm}$ between seeds within the row. The net harvest area was $4.8 \mathrm{~m}^{2}$ per plot, the central two rows. The spacing between plots and blocks was $1 \mathrm{~m}$ and $1.5 \mathrm{~m}$, respectively. All agronomic management practices were carried out equally and properly as per the recommendations.

2.3. Data Collection and Data Analysis. Data for plant height, number of pods per plant, and number of seeds per pod were collected on the basis of five sample plants which were randomly taken from the two central rows, and the average of five samples was used for analysis, while days to $50 \%$ flowering, days to $90 \%$ maturity, grain yield, and 100 seed weight were collected on the basis of the net plot (i.e., two central rows).

Different statistical software packages were used to analyse the data. SAS [18] was used for analysis of variance of the individual environments and combined over locations [19]. SPAR 2.0 was used for regression coefficient (bi) and deviation from regression $\left(S^{2} \mathrm{di}\right)$, and GenStat $\left(18^{\text {th }}\right.$ edition, $2015)$ was used for cultivar performance $\left(p_{i}\right)$ and Wricke's ecovalence $(\mathrm{Wi})$. The combined analysis of variance across the environment was carried out using a mixed model (genotype: fixed, location: random) in order to determine the differences between genotypes across environments, among environments and their interaction. The F-max method of Hartley [20] was used to assess the homogeneity of error variances prior to doing combined analysis over the environment. However, location four (Melkassa) was an outlier in terms of error variance; hence, it was removed from the combined analysis. Due to this, the combined analysis of variance for grain yield and yield-related traits of 25 cowpea genotypes tested was conducted for five environments. Various stability analyses were computed for grain yield. Mean comparison using Duncan's Multiple Range Test (DMRT) was performed to explain the significant differences among the means of genotypes and environments.

\section{Results and Discussion}

3.1. Analysis of Variance for Individual Environments. Analysis of variance for grain yield $\left(\mathrm{kg} \mathrm{ha}^{-1}\right)$ of the 25 cowpea genotypes tested in six environments is presented in Table 2. Analysis of variance for each environment showed a highly significant $(P<0.01)$ variation in grain yield among cowpea genotypes in all tested environments. This indicated the presence of performance variation among the tested cowpea genotypes for grain yield. Likewise, El-Shaieny et al. [21]; Santos et al. [22]; Ishiyaku et al. [23]; and Tariku [24] in cowpea and Abele [25] and Tullu [26] in common bean reported large variation in grain yield 
TABLE 1: Description of the test environments.

\begin{tabular}{|c|c|c|c|c|c|c|c|}
\hline \multirow[t]{2}{*}{ Environments } & \multirow[t]{2}{*}{ Soil type } & \multirow[t]{2}{*}{ Altitude (masl) } & \multirow[t]{2}{*}{ Average rainfall $(\mathrm{mm})$} & \multicolumn{2}{|c|}{$\begin{array}{c}\text { Temperature } \\
\left({ }^{\circ} \mathrm{C}\right)\end{array}$} & \multicolumn{2}{|c|}{ Geographical location } \\
\hline & & & & Min & Max & Latitude $(\mathrm{N})$ & Longitude (E) \\
\hline Sekota & Vertisol & 1850 & 789 & 12.9 & 32.9 & $12^{\circ} 14^{\prime}$ & $38^{\circ} 30^{\prime}$ \\
\hline Kobo & Vertisol & 1450 & 673.4 & 13 & 34 & $12^{\circ} 8^{\prime}$ & $39^{\circ} 18^{\prime}$ \\
\hline Sirinka & Vertisol & 1880 & 876 & 13.6 & 27.3 & $11^{\circ} 08^{\prime}$ & $39^{\circ} 28^{\prime}$ \\
\hline Melkassa & Andosol & 1500 & 763 & 14 & 24.8 & $8^{\circ} 30^{\prime}$ & $39^{\circ} 21^{\prime}$ \\
\hline Miesso & Vertisol & 1332 & 787 & 14.9 & 28.2 & $9^{\circ} 28^{\prime}$ & $38^{\circ} 08^{\prime}$ \\
\hline Babile & Spodosols & 1650 & 671 & 15.5 & 28.1 & $9^{\circ} 30^{\prime}$ & $42^{\circ} 21^{\prime}$ \\
\hline
\end{tabular}

Source: the Melkassa Agricultural Research Center (MARC), Sirinka Agricultural Research Center (SARC), and Sekota Dry Land Agricultural Research Center (SDARC).

TABle 2: Mean grain yield $\left(\mathrm{kg} \mathrm{ha}^{-1}\right)$ of 25 cowpea landraces tested at six environments in the 2019 cropping season.

\begin{tabular}{|c|c|c|c|c|c|c|c|c|c|}
\hline \multirow{2}{*}{ Code } & \multirow{2}{*}{ Genotypes } & \multicolumn{6}{|c|}{ Environments } & \multirow{2}{*}{ GGM } & \multirow{2}{*}{ Rank } \\
\hline & & Sekota & Kobo & Sirinka & Melkassa & Miesso & Babile & & \\
\hline$G 1$ & NLLP_CPC_07-47 & $1761.1^{\mathrm{ef}}$ & $1776.5^{\text {ghi }}$ & $2603.2^{\mathrm{a}}$ & $2642.1^{\text {bcde }}$ & $1800.1^{\text {efg }}$ & $2196.0^{\text {cde }}$ & $2129.8^{\mathrm{b}-\mathrm{h}}$ & 11 \\
\hline$G 2$ & NLL_CPC_07-74 & $1900.0^{\text {abcde }}$ & $2538.3^{\mathrm{cd}}$ & $2401.6^{\mathrm{ab}}$ & $2581.5^{\text {bcdef }}$ & $2729.5^{\mathrm{bcd}}$ & $1506.7^{\text {ghij }}$ & $2276.3^{\mathrm{bc}}$ & 3 \\
\hline G3 & NLLP_CPC_07-168 & $2261.1^{\mathrm{a}}$ & $1255.3^{\operatorname{lm}}$ & $2486.0^{\mathrm{ab}}$ & $1900.6^{\mathrm{ef}}$ & $2980.7^{\mathrm{abc}}$ & $1242.3^{\mathrm{jkl}}$ & $2021.0^{\mathrm{g}-\mathrm{j}}$ & 16 \\
\hline G4 & NLLP_CPC_07-27 & $2094.4^{\text {abcde }}$ & $2394.0^{\text {cde }}$ & $1974.5^{\mathrm{cd}}$ & $2377.0^{\text {bcdef }}$ & $3073.8^{\mathrm{abc}}$ & $1588.3^{\text {fghij }}$ & $2250.3^{\mathrm{bcd}}$ & 6 \\
\hline G5 & NLLP_CPC_07-05 & $1754.2^{\mathrm{f}}$ & $2170.4^{\mathrm{ef}}$ & $1765.3^{\mathrm{d}}$ & $2660.3^{\text {bcde }}$ & $3065.4^{\mathrm{abc}}$ & $1055.0^{1}$ & $2078.4^{\mathrm{c}-\mathrm{i}}$ & 12 \\
\hline G6 & NLLP_CPC_07-01 & $2014.6^{\text {abcde }}$ & $1905.6^{\mathrm{fgh}}$ & $743.2^{\mathrm{i}}$ & $2525.8^{\text {bcdef }}$ & $2664.9^{\mathrm{bcd}}$ & $1446.6^{\text {hijk }}$ & $1883.5^{\mathrm{i}-1}$ & 19 \\
\hline G7 & NLL_CPC_07-49 & $1847.9^{\text {cde }}$ & $1491.0^{\mathrm{ijkl}}$ & $1868.2^{\mathrm{cd}}$ & $2891.0^{\mathrm{abc}}$ & $2756.8^{\mathrm{abcd}}$ & $2724.8^{\mathrm{a}}$ & $2263.3^{\mathrm{bc}}$ & 5 \\
\hline G8 & NLLP_CPC_07-77 & $1858.4^{\text {bcde }}$ & $1406.8^{\mathrm{jklm}}$ & $2458.4^{\mathrm{ab}}$ & $1905.2^{\text {def }}$ & $2635.2^{\mathrm{bcd}}$ & $1408.0^{\mathrm{hijkl}}$ & $1945.3^{\mathrm{h}-1}$ & 18 \\
\hline G9 & NLL_CPC_07-46A & $2198.6^{\mathrm{abc}}$ & $1938.4^{\mathrm{fgh}}$ & $1154.2^{\text {fgh }}$ & $1907.7^{\text {def }}$ & $3074.6^{\mathrm{abc}}$ & $1969.9^{\mathrm{def}}$ & $2040.6^{\mathrm{g}-\mathrm{i}}$ & 15 \\
\hline G10 & ACC 211557 & $1775.0^{\mathrm{def}}$ & $1661.6^{\mathrm{hij}}$ & $1982.0^{\mathrm{cd}}$ & $2532.4^{\text {bcdef }}$ & $2615.3^{\mathrm{bcd}}$ & $1710.7^{\mathrm{fgh}}$ & $2046.2^{\mathrm{e}-\mathrm{i}}$ & 14 \\
\hline G11 & ACC222890 & $1712.5^{\mathrm{ef}}$ & $1299.7^{\mathrm{klm}}$ & $1625.8^{\mathrm{def}}$ & $2482 .^{3 \mathrm{bcdef}}$ & $1027.2^{\mathrm{h}}$ & $1062.6^{\mathrm{kl}}$ & $1535.0^{\circ}$ & 25 \\
\hline$G 12$ & Dass 002 & $1393.1^{\mathrm{f}}$ & $2174.3^{\mathrm{ef}}$ & $1126.6^{\mathrm{fgh}}$ & $1960.8^{\mathrm{def}}$ & $1465.3^{\text {gh }}$ & $1661.3^{\text {fghi }}$ & $1630.2^{\text {no }}$ & 24 \\
\hline G13 & Dass 007 & $1837.5^{\text {cde }}$ & $2671.6^{\mathrm{bc}}$ & $1370.2^{\text {ef }}$ & $2199.7^{\text {cdef }}$ & $2994.6^{\mathrm{abc}}$ & $1246.8^{\mathrm{jkl}}$ & $2053.4^{\mathrm{d}-\mathrm{i}}$ & 13 \\
\hline$G 14$ & NLLP_CPC_07-69 & $1400.0^{\mathrm{f}}$ & $1729.0^{\mathrm{ghi}}$ & $1802.3^{\mathrm{cd}}$ & $1849.5^{\mathrm{f}}$ & $1705.1^{\mathrm{fg}}$ & $1396.1^{\text {hijkl }}$ & $1647.0^{\mathrm{mno}}$ & 23 \\
\hline G15 & NLLP_CPC_07_ & $1865.3^{\text {abcde }}$ & $1206.2^{\mathrm{m}}$ & $1355.0^{\text {ef }}$ & $2424.2^{\text {bcdef }}$ & $2787.7^{\mathrm{abcd}}$ & $1311.0^{\mathrm{ijkl}}$ & $1824.9^{\mathrm{klm}}$ & 21 \\
\hline G16 & ACC 233403 & $2038.9^{\text {abcde }}$ & $2522.7^{\mathrm{cd}}$ & $992.9^{\mathrm{ghi}}$ & $3083.2^{\mathrm{ab}}$ & $2784.6^{\mathrm{abcd}}$ & $2320.1^{\mathrm{bcd}}$ & $2290.4^{\mathrm{b}}$ & 2 \\
\hline G17 & NLLP_CPC_07-28 & $1406.9^{\mathrm{f}}$ & $1915.9^{\text {fgh }}$ & $809.3^{\text {hi }}$ & $2360.2^{\text {bcdef }}$ & $2256.8^{\mathrm{def}}$ & $1841.7^{\mathrm{efg}}$ & $1765.1 \mathrm{l}^{\mathrm{mn}}$ & 22 \\
\hline$G 18$ & NLLP_CPC_07-46B & $1868.8^{\text {abcde }}$ & $1570.0^{\mathrm{ijk}}$ & $1415.3^{\text {ef }}$ & $3433.4^{\mathrm{a}}$ & $1746.6^{\mathrm{fg}}$ & $1940.3^{\mathrm{ef}}$ & $1995.7^{\mathrm{g}-\mathrm{k}}$ & 17 \\
\hline G19 & AC̄C $24 \overline{4} 804$ & $1768.1^{\text {def }}$ & $2592.7^{\mathrm{c}}$ & $836.9^{\text {hi }}$ & $2523.6^{\text {bcdef }}$ & $1793.1^{\mathrm{efg}}$ & $1512.9^{\text {ghij }}$ & $1837.9^{\mathrm{jkl}}$ & 20 \\
\hline G20 & NLLP_CPC_07-29 & $1997.2^{\text {abcde }}$ & $2004.1^{\mathrm{fg}}$ & $1961.1^{\mathrm{cd}}$ & $2273.7^{\text {cdef }}$ & $3090.4^{\mathrm{abc}}$ & $1952.2^{\mathrm{def}}$ & $2213.1^{b-f}$ & 8 \\
\hline$G 21$ & ACC 223402 & $2118.8^{\mathrm{abcd}}$ & $2309.9^{\text {de }}$ & $1667.3^{\text {de }}$ & $2637.2^{\text {bcde }}$ & $2708.0^{\mathrm{bcd}}$ & $1749.9^{\mathrm{fgh}}$ & $2198.5^{\mathrm{b}-\mathrm{f}}$ & 9 \\
\hline G22 & NLLP_CPC_07_48B & $1816.7^{\text {cde }}$ & $1674.0^{\mathrm{hij}}$ & $2321.9^{\mathrm{ab}}$ & $2460.1^{\text {bcdef }}$ & $2352.9^{\mathrm{de}}$ & $2340.5^{\mathrm{bc}}$ & $2161.0^{\mathrm{b}-\mathrm{g}}$ & 10 \\
\hline$G 23$ & NLLP_CPC_07-03 & $2087.5^{\text {abcde }}$ & $1525.3^{\mathrm{ijkl}}$ & $1199.6^{\mathrm{fg}}$ & $2691.6^{\mathrm{bcd}}$ & $3372.0^{\mathrm{a}}$ & $2578.8^{\mathrm{ab}}$ & $2242.5^{\mathrm{b}-\mathrm{e}}$ & 7 \\
\hline G24 & NLLP_CPC 07-55 & $2247.2^{\mathrm{ab}}$ & $3060.0^{\mathrm{a}}$ & $2150.4^{\mathrm{cd}}$ & $2928.5^{\mathrm{abc}}$ & $3205.1^{\mathrm{ab}}$ & $2203.3^{\text {cde }}$ & $2632.4^{\mathrm{a}}$ & 1 \\
\hline \multirow[t]{3}{*}{$G 25$} & Kanketi & $2181.3^{\mathrm{abc}}$ & $2871.6^{\mathrm{ab}}$ & $1831.7^{\mathrm{cd}}$ & $2945.1^{\mathrm{abc}}$ & $2534.1^{\mathrm{cd}}$ & $1275.9^{\mathrm{ijkl}}$ & $2273.3^{b c}$ & 4 \\
\hline & EGM & $1888.2^{* *}$ & $1986.6^{* *}$ & $1676.1^{* *}$ & $2487.1^{* *}$ & $2528.8^{* *}$ & $1729.7^{* *}$ & 2049.4 & \\
\hline & CV (\%) & 10.37 & 7.73 & 11.44 & 15.89 & 12.69 & 11.72 & & \\
\hline
\end{tabular}

${ }^{* *}=$ significant at $P<0.01, \mathrm{GGM}=$ genotypic grand mean, EGM = environmental grand mean, CV $(\%)=$ coefficient of variation in percent.

performance among different tested genotypes across environments.

Among the testing environments, the general performances of the genotypes for grain yield were the highest at Miesso as compared to the other six environments with a mean grain yield of $2528.8 \mathrm{~kg} \mathrm{ha}^{-1}$ followed by Melkassa $\left(2487.1 \mathrm{~kg} \mathrm{ha}^{-1}\right)$ and Kobo $\left(1986.6 \mathrm{~kg} \mathrm{ha}^{-1}\right)$. The superior performance of genotypes at Miesso and Melkassa can be attributed to the uniform distribution of rainfall during the season (Table 3). The lowest grain yield was obtained at Sirinka with a mean yield of $1676.1 \mathrm{~kg} \mathrm{ha}^{-1}$. This may be due to heavy rainfall and hail that occurred at the vegetative stage. Babile was the $2^{\text {nd }}$ least-performing environment with mean grain yield of $1729.7 \mathrm{~kg} \mathrm{ha}^{-1}$, which may be due to a small amount and erratic rainfall during the growing season.

As indicated in Table 2, the tested genotypes showed inconsistent yield advantage across environments. Genotype NLLP_CPC 70-55 scored the highest mean grain yield $\left(3060.0 \mathrm{~kg} \mathrm{ha}^{-1}\right)$ at Kobo followed by Kanketi $\left(2871.6 \mathrm{~kg} \mathrm{ha}^{-1}\right)$ and Dass 007 (2671.6 $\left.\mathrm{kg} \mathrm{ha}^{-1}\right)$, whereas NLLP_CPC_07-168 $\left(2261.1 \mathrm{~kg} \mathrm{ha}^{-1}\right)$, NLLP_CPC 07-55 (2247.2 $\left.\mathrm{kg} \mathrm{ha}^{-1}\right)$, and NLLP_CPC_46A $\left(2198.6 \mathrm{~kg} \mathrm{ha}^{-1}\right)$ were the three top-yielder genotypes at Sekota without a significant difference among them. At Sirinka, NLLP_CPC_07-47, NLLP_CPC_07-168, and NLLP_CPC_07-77 were the three best yielders with a mean grain yield of $2603.2 \mathrm{~kg} \mathrm{ha}^{-1}, 2486.0 \mathrm{~kg} \mathrm{ha}^{-1}$, and 
TABLE 3: Monthly meteorological data of the test locations during the growing period.

\begin{tabular}{|c|c|c|c|c|c|c|}
\hline Location & & Jun & July & August & September & October \\
\hline \multirow{4}{*}{ Sekota } & $\begin{array}{c}\mathrm{RF} \\
(\mathrm{mm})\end{array}$ & 57.4 & 125.6 .0 & 110 & 76.4 & 0 \\
\hline & $\begin{array}{l}\mathrm{T} \min \\
\left({ }^{\circ} \mathrm{C}\right)\end{array}$ & 17 & 16.2 & 16.1 & 17.6 & 18.5 \\
\hline & $\begin{array}{l}\mathrm{T} \max \\
\left({ }^{\circ} \mathrm{C}\right)\end{array}$ & 28.5 & 26.8 & 27.1 & 28.1 & 28.4 \\
\hline & T mean & 22.75 & 21.5 & 21.6 & 22.85 & 23.5 \\
\hline \multirow{4}{*}{ Kobo } & $\begin{array}{c}\mathrm{RF} \\
(\mathrm{mm})\end{array}$ & 46.6 & 204.1 & 267.6 & 102.3 & 38.8 \\
\hline & $\begin{array}{l}\mathrm{T} \min \\
\left({ }^{\circ} \mathrm{C}\right)\end{array}$ & 16.5 & 15.8 & 14.9 & 14.9 & 15 \\
\hline & $\begin{array}{c}\mathrm{T} \max \\
\left({ }^{\circ} \mathrm{C}\right)\end{array}$ & 28.7 & 28.2 & 25.7 & 26.3 & 27.4 \\
\hline & T mean & 22.6 & 22 & 20.3 & 20.6 & 21.2 \\
\hline \multirow{4}{*}{ Sirinka } & $\begin{array}{c}\mathrm{RF} \\
(\mathrm{mm})\end{array}$ & 89.3 & 285.3 & 208.1 & 143.4 & 50.4 \\
\hline & $\underset{\left({ }^{\circ} \mathrm{C}\right)}{\mathrm{T} \min }$ & 15.6 & 15.9 & 14.9 & 15.4 & 14.7 \\
\hline & $\begin{array}{c}\mathrm{T} \max \\
\left({ }^{\circ} \mathrm{C}\right)\end{array}$ & 24.5 & 25.1 & 24.3 & 25.2 & 24.1 \\
\hline & T mean & 20 & 20.5 & 19.6 & 20.3 & 14.7 \\
\hline \multirow{4}{*}{ Melkassa } & $\begin{array}{c}\mathrm{RF} \\
(\mathrm{mm})\end{array}$ & 75.7 & 100.7 & 158.7 & 120.2 & 83.3 \\
\hline & $\frac{\mathrm{T} \min }{\left({ }^{\circ} \mathrm{C}\right)}$ & 15 & 14.8 & 14.6 & 14.3 & 11.1 \\
\hline & $\begin{array}{c}\mathrm{T} \max \\
\left({ }^{\circ} \mathrm{C}\right)\end{array}$ & 27 & 25.7 & 26.1 & 26.7 & 27.8 \\
\hline & T mean & 21 & 20.3 & 20.4 & 20.5 & 19.5 \\
\hline \multirow{4}{*}{ Miesso } & $\begin{array}{c}\mathrm{RF} \\
(\mathrm{mm})\end{array}$ & 42.5 & 70.7 & 123.1 & 92.6 & 53.9 \\
\hline & $\begin{array}{l}\mathrm{T} \min \\
\left({ }^{\circ} \mathrm{C}\right)\end{array}$ & 15.6 & 14.6 & 14.2 & 14.6 & 14.3 \\
\hline & $\begin{array}{l}\mathrm{T} \max \\
\left({ }^{\circ} \mathrm{C}\right)\end{array}$ & 25.9 & 22.5 & 23 & 24 & 25.8 \\
\hline & $\mathrm{T}$ mean & 20.75 & 18.55 & 18.6 & 19.3 & 20.05 \\
\hline \multirow{4}{*}{ Babile } & $\begin{array}{c}\mathrm{RF} \\
(\mathrm{mm})\end{array}$ & 82.2 & 5.2 & 112.8 & 55 & 86.4 \\
\hline & $\frac{\mathrm{T} \min }{\left({ }^{\circ} \mathrm{C}\right)}$ & 18.6 & 18.6 & 17.5 & 16.3 & 14.7 \\
\hline & $\begin{array}{c}\mathrm{T} \max \\
\left({ }^{\circ} \mathrm{C}\right)\end{array}$ & 29.2 & 28.2 & 30.5 & 31.7 & 31.3 \\
\hline & $\mathrm{T}$ mean & 23.9 & 23.4 & 24 & 24 & 23 \\
\hline
\end{tabular}

$\mathrm{RF}=$ rain fall; $T$ =temperature; $\quad$ Min = minimum; $\quad$ Max = maximum; ${ }^{\circ} \mathrm{C}=$ degree centigrade; $\mathrm{mm}=$ millimeter .

$2458.4 \mathrm{~kg} \mathrm{ha}^{-1}$, respectively. At the same time, NLLP_CPC07-46B (3433.4 kg ha $\left.{ }^{-1}\right)$, ACC $233403\left(3083.2 \mathrm{~kg} \mathrm{ha}^{-1}\right)$, Kanketi (2945.1 kg ha $\left.{ }^{-1}\right)$, and NLLP_CPC 70-55 (2928.5 kg $\mathrm{ha}^{-1}$ ) were the highest-yielder genotypes in Melkassa without a significant variation between them. At Miesso, NLLP_CPC_07-03 was the highest yielder $\left(3372.0 \mathrm{~kg} \mathrm{ha}^{-1}\right)$ followed by NLLP_CPC $07-55\left(3205.1 \mathrm{~kg} \mathrm{ha}^{-1}\right)$ and NLLP_CPC_07-29 $\left(3090.4 \mathrm{~kg} \mathrm{ha}^{-1}\right)$, respectively, without a significant variation between them. At Babile, NLLP_CPC_07-49, NLLP_CPC_07-03, and NLLP_CPC_07$48 \mathrm{~B}$ were the three top yielders with grain yields of $2724.8 \mathrm{~kg}$ $\mathrm{ha}^{-1}, 2578.8 \mathrm{~kg} \mathrm{ha}^{-1}$, and $2340.5 \mathrm{~kg} \mathrm{ha}^{-1}$, respectively.
3.2. Combined Analysis of Variance over Five Environments. For combined analysis of variance, the homogeneity of error variances was tested using the F-max method of Hartley [20], which is based on the ratio of the larger mean square of error (MSE) from the separate analysis of variance to the smaller mean square of error as $F$ - ratio = larger MSE/ smaller MSE. If the larger error mean square is not threefold larger than the smaller error mean square, the error variance was considered homogeneous [27] and allowed pooled analysis across environments. However, location four (Melkassa) was an outlier in terms of error variance; hence, it was removed from the combined analysis. Due to this, the combined analysis of variance for grain yield and yield-related traits of 25 cowpea genotypes tested was conducted for five environments (Tables 4 and 5).

The analysis showed that cowpea grain yield was significantly $(P<0.01)$ affected by the environment, genotype, and GEI. The significance of GEI indicated that the relative performances of the genotypes were not consistent across the test environments and the environments had different effects on the yield potential of the genotypes. This, in turn, suggested the need to conduct further analysis on the genotype by environment interaction to understand the nature of the interaction and to accomplish stability analysis for identifying genotypes with stable performances across environments and/or those that fit for specific adaptation. In agreement with this finding, El-Shaieny et al. [28]; Santos et al. [22]; and Ishiyaku et al. [23] in cowpea and Firew [29]; Abele [25]; and Tadele et al. [30] in common bean reported the significant effects of the genotype, environment, and genotype by environment interaction on yield and yieldrelated traits.

In this study, the largest variance was explained by the genotype by environment interaction (49.55\%), followed by the environment effect (27.45\%), genotype effect $(20.9 \%)$, and $2.07 \%$ of replication effect (Table 4 ). Only $9.21 \%$ of total variation remained unexplained (as error). A large yield variation explained by the GEI and environment indicated that genotypes had various performances across environments and the environments were diverse, with large difference among environmental means causing most of the variation in grain yield. In line with this, many researchers reported the dominance of the environmental effect in the combined analysis of grain yield (Abele [25]; Tariku $[24,26])$. Hence, the GEI maintained or exerted about more than double times larger effect than the genotype, which complicates the selection of superior and adaptable genotypes. Pham and Kang [31] indicated that, since GEI minimize the usefulness of genotype effects alone, it is, thus, imperative that yield levels, adaptation, and stability are taken into account in the multilocation trial. Therefore, simultaneous consideration of both high mean yield (genotype main effect) and GEI stability is very crucial in selecting superior genotypes from evaluated cowpea genotypes.

Combined analysis of variance revealed a highly significant $(P<0.01)$ variation among the tested genotypes for days to $50 \%$ flowering, days to $90 \%$ maturity, plant height, number of pods per plant, number of seeds per pod, 
TABLE 4: Combined ANOVA for grain yield $\left(\mathrm{kg} \mathrm{ha}^{-1}\right)$ of 25 cowpea genotypes tested at five environments.

\begin{tabular}{lcccc}
\hline Source of variation & Degrees of freedom & Sum of square & Mean square & Total variation explained (\%) \\
\hline Genotype & 24 & 26479319.3 & $1103304.97^{* *}$ & 20.9 \\
Environment & 4 & 34726016.9 & $8681504.24^{* *}$ & 27.45 \\
Rep (env.) & 10 & 2615788.7 & $261578.87^{* *}$ & 2.07 \\
Interaction & 96 & 62679547.1 & $652911.95^{* *}$ & 49.55 \\
Pooled error & 240 & 11652665.5 & 48552.8 & 9.21 \\
Total & 374 & 126500672.0 & & \\
\hline
\end{tabular}

** $=$ Significant at $P<0.01$.

TABLE 5: Mean square from combined ANOVA for yield-related traits of 25 cowpea landraces tested at five environments.

\begin{tabular}{lccccccc}
\hline Source & Df & DF & DM & $P H$ & PPP & SPP & HSW \\
\hline Genotype & 24 & $41^{* *}$ & $100^{* *}$ & $1135^{* *}$ & $26^{* *}$ & $6^{* *}$ & $1103305^{* *}$ \\
Environment & 4 & $1668^{* *}$ & $3060^{* *}$ & $98526^{* *}$ & $5579^{* *}$ & $203^{* *}$ & $8681504^{* *}$ \\
Rep (env.) & 10 & $7 \mathrm{~ns}$ & $10 \mathrm{~ns}$ & $243^{* *}$ & $109^{* *}$ & $4^{* *}$ & $261579^{* *}$ \\
Interaction & 96 & $28^{* *}$ & $74^{* *}$ & $733^{* *}$ & $42^{* *}$ & $7^{* *}$ & $652912^{* *}$ \\
Pooled error & 240 & 4 & 10 & 88 & 5 & 2 & 48553 \\
\hline
\end{tabular}

${ }^{* *}=$ Significant at $P<0.01 ;{ }^{*}=$ significant at $P<0.05, \mathrm{~ns}=$ nonsignificant; $\mathrm{df}=$ degrees of freedom; $\mathrm{DF}=$ days to flowering; $\mathrm{DM}=\mathrm{days}$ to maturity; $\mathrm{PH}=$ plant height; $\mathrm{PPP}=$ pod per plant; $\mathrm{SPP}=$ seed per pod; HSW = hundred seed weight.

grain yield, and hundred seed weight (Table 6). In this study, the genotype $\times$ environment interaction showed highly significant differences and the tested genotypes showed rank change and strong interaction. Therefore, the mean performance of genotypes cross the tested environments was interpreted using simple effects (i.e., mean of each genotype at each location) to provide relevant information.

\subsection{Analysis of Variance for Grain Yield from Eberhart and} Russell's Model. The significant mean squares for $G \times E$ interaction in the general ANOVA (Table 4) suggested the importance of partitioning the genotype by the environment interaction effect into the environment (linear), $G \times E$ (linear) interaction effects (the sum of squares due to regression or $b_{i}$ ), and unexplained deviation from linear regression (pooled deviation mean squares or $S^{2} \mathrm{di}$ ). The results of ANOVA for grain yield from Eberhart and Russell's model are presented in Table 7.

In the joint regression analysis of variance for grain yield, there was a highly significant difference for genotypes and a significant difference for genotype $x$ environment (linear) sources of variation. This indicated contrasts between the environments and the occurrence of the differential response of genotypes across environments. The linear and nonlinear parameters provide an adequate account of the dynamic response of genotypes to changing environments and are used with the mean performance of genotypes to assess the potentialities of different genotypes [32]. The significant $G \times E$ (linear) interaction indicated that the stability parameter " $b_{i}$ " estimated by the linear response to change in environment was not the same for all genotypes, and the variability of genotypes for performance is partially unpredictable. These results are in agreement with those reported by Sarvamangala et al. [33] and Nunes et al. [34] in cowpea.
According to Eberhart and Russell's [21] model, a stable genotype should have high mean yield, the regression coefficient approximating to a unity $\left(b_{i}=1\right)$, and deviation from regression $\left(\mathrm{S}^{2} \mathrm{di}\right)$ nearly equal to zero. The regression coefficient $\left(b_{i}\right)$ measures the response of genotypes to environments. When the regression coefficient of the genotype is nonsignificantly different from unity $\left(b_{i}=1\right)$, the genotype is said to have average response to environmental change and suitable to both poor and good environments, while if the $b_{i}$ value of genotypes is significantly greater than unity $\left(b_{i}>1\right)$, the genotype is highly responsive to environmental change and it is suitable only for a good environment. When the genotype $b_{i}$ value is significantly less than unity $\left(b_{i}<1\right)$, it indicates that the genotype is less responsive and it is suitable for poor environments [35]. Accordingly, many genotypes with mean grain yield lower and above the grand mean had $b_{i}$ values which were nonsignificantly different from unity $\left(b_{i}=1\right)$, indicating their average response to both poor and good environments (Table 8). From those genotypes, G16, $G 20, G 24, G 2$, and $G 7$ had positive and nearly a unity (bi $=1$ ) regression coefficient values that indicated average responsiveness and that the genotypes were suitable for all environments. These genotypes had also higher mean yield than overall mean of genotypes, suggesting that they are desirable for cultivation in all environments. In contrast to this, genotypes $G 5, G 6, G 10, G 15$, and $G 23$ had the $b_{i}$ values significantly greater than unity, indicating that these genotypes are highly responsive to environmental change and are suitable only for good environments. Similarly, Rodriguez [36] and Adewale et al. [37] reported differences in cowpea genotypes for their responsiveness and stability for grain yield tested at different environments.

The mean sums of squares due to pooled deviation from regression were highly significant $(P \leq 0.01)$ for grain yield of all genotypes except 621 , indicating the importance of a nonlinear genotype by environment interaction, and the genotypes were unstable across environments (Table 8). 
TABLE 6: Combined means of grain yield and yield-related traits of cow pea landrace grown at six environments in the 2019 main cropping season.

\begin{tabular}{|c|c|c|c|c|c|c|c|c|}
\hline Code & Genotypes & DF & $\mathrm{DM}$ & PH & PDP & SDPP & GY & HSW \\
\hline G1 & NLLP_CPC_07-47 & $58.3^{\text {cdef }}$ & $87.7^{\text {bcde }}$ & $54.9^{\mathrm{i}}$ & $17.6^{\mathrm{ab}}$ & $11.8^{\mathrm{i}}$ & $2027.4^{\text {cde }}$ & $11.3^{\text {cdefg }}$ \\
\hline G2 & NLL_CPC_07-74 & $58.7^{\text {cdef }}$ & $85.4^{\mathrm{efg}}$ & $71.0^{\mathrm{defg}}$ & $15.1^{\text {defgh }}$ & $10.9^{\text {defg }}$ & $2215.2^{\mathrm{bc}}$ & $11.3^{\text {bcdef }}$ \\
\hline G3 & NLLP_CPC_07-168 & $56.5^{\text {hijk }}$ & $84.5^{\mathrm{efgh}}$ & $60.4^{\mathrm{i}}$ & $15.1^{\text {defgh }}$ & $11.6^{\mathrm{hi}}$ & $2045.1^{\text {bcde }}$ & $8.31^{\mathrm{mn}}$ \\
\hline G4 & NLLP_CPC_07-27 & $56.1^{\mathrm{ijk}}$ & $82.6^{\mathrm{hi}}$ & $62.8^{\text {gh }}$ & $14.8^{\text {efgh }}$ & $11.8^{\mathrm{ab}}$ & $2225.0^{\mathrm{b}}$ & $8.9^{\mathrm{klm}}$ \\
\hline G5 & NLLP_CPC_07-05 & $58.1^{\text {cdefgh }}$ & $81.7^{\mathrm{i}}$ & $74.7^{\text {bcdef }}$ & $15.1^{\text {defgh }}$ & $9.8 \mathrm{e}$ & $1962.0^{\mathrm{e}}$ & $12.3^{\mathrm{b}}$ \\
\hline G6 & NLLP_CPC_07-01 & $58.6^{\text {cdef }}$ & $86.7^{\text {cdef }}$ & $77.3^{\mathrm{bcd}}$ & $15.5^{\text {cdefgh }}$ & $11.5^{\mathrm{abc}}$ & $1755.0^{\mathrm{f}}$ & $8.2^{\operatorname{lmn}}$ \\
\hline G7 & NLL_CPC_07-49 & $61.4^{\mathrm{a}}$ & $89.0^{\mathrm{abc}}$ & $66.6^{\mathrm{fgh}}$ & $18.2^{\mathrm{a}}$ & $10.9^{\text {bcde }}$ & $2137.7^{\text {bcde }}$ & $10.8^{\mathrm{efgh}}$ \\
\hline G8 & NLLP_CPC_07-77 & $58.5^{\text {cdefg }}$ & $89.1^{\mathrm{abc}}$ & $83.1^{\mathrm{ab}}$ & $13.7^{\mathrm{h}}$ & $10.5^{\text {cde }}$ & $1953.3^{\mathrm{e}}$ & $8.7^{\mathrm{klm}}$ \\
\hline G9 & NLL_CPC_07-46A & $55.5^{\mathrm{jk}}$ & $81.1 \mathrm{i}$ & $68.8^{\text {defg }}$ & $13.9^{\mathrm{h}}$ & $9.9^{\mathrm{e}}$ & $2067.2^{\text {bcde }}$ & $9.9^{\text {hij }}$ \\
\hline$G 10$ & ACC 211557 & $57.4^{\text {fghi }}$ & $87.9^{\text {abcde }}$ & $85.6^{\mathrm{a}}$ & $16.8^{\mathrm{abcde}}$ & $10.5^{\text {cde }}$ & $1948.9^{\mathrm{e}}$ & $11.1^{\text {defg }}$ \\
\hline$G 11$ & ACC222890 & $57.9^{\mathrm{efgh}}$ & $88.7^{\mathrm{abc}}$ & $75.9^{\text {bcde }}$ & $15.6^{\mathrm{h}}$ & $12.3^{\mathrm{a}}$ & $1345.6^{\mathrm{h}}$ & $7.9^{\mathrm{mn}}$ \\
\hline G12 & Dass 002 & $58.4^{\text {cdefg }}$ & $89.3^{\mathrm{abc}}$ & $75.9^{\text {bcde }}$ & $14.7^{\text {bcdefgh }}$ & $10.3^{\mathrm{de}}$ & $1564.1^{\mathrm{g}}$ & $7.3^{n}$ \\
\hline G13 & Dass 007 & $55.1^{\mathrm{k}}$ & $83.2^{\text {ghi }}$ & $73.3^{\text {cdef }}$ & $16.0^{\text {fgh }}$ & $11.5^{\mathrm{abc}}$ & $2024.1^{\text {de }}$ & $9.0^{\mathrm{jkl}}$ \\
\hline G14 & NLLP_CPC_07-69 & $58.1^{\text {defgh }}$ & $87.9^{\text {abcde }}$ & $77.4^{\mathrm{bcd}}$ & $14.1^{\text {cbdefg }}$ & $10.4^{\text {cde }}$ & $1606.5^{\mathrm{fg}}$ & $9.1^{\mathrm{jkl}}$ \\
\hline G15 & NLLP_CPC_07_ & $58.0^{\mathrm{defgh}}$ & $88.6^{\mathrm{abcd}}$ & $70.6^{\text {defg }}$ & $17.0^{\mathrm{gh}}$ & $10.8^{\text {bcde }}$ & $1705.0^{\mathrm{fg}}$ & $10.0^{\mathrm{hij}}$ \\
\hline G16 & ACC 233403 & $57.9^{\text {defgh }}$ & $85.9^{\mathrm{def}}$ & $77.0^{\mathrm{bcd}}$ & $13.9^{\mathrm{abcd}}$ & $11.9^{\mathrm{ab}}$ & $2131.9^{\text {bcde }}$ & $11.5^{\text {bcde }}$ \\
\hline$G 17$ & NLLP_CPC_07-28 & $60.9^{\mathrm{ab}}$ & $89.7^{\mathrm{ab}}$ & $70.4^{\text {defg }}$ & $14.4^{\mathrm{h}}$ & $10.8^{\text {bcde }}$ & $1646.1^{\mathrm{fg}}$ & $10.6^{\mathrm{efgh}}$ \\
\hline G18 & NLLP_CPC_07-46B & $59.6^{\mathrm{bcd}}$ & $88.9^{\mathrm{abc}}$ & $77.2^{\mathrm{bcd}}$ & $14.4^{\mathrm{gh}}$ & $10.9^{\text {bcde }}$ & $1708.2^{\mathrm{fg}}$ & $9.3^{\mathrm{ijk}}$ \\
\hline G19 & ACC $24 \overline{4} 804$ & $59.4 \mathrm{cde}$ & $87.2^{\text {bcde }}$ & $67.4^{\text {efgh }}$ & $16.7^{\mathrm{gh}}$ & $10.9^{\text {bcde }}$ & $1700.7^{\mathrm{fg}}$ & $12.0^{\mathrm{bcd}}$ \\
\hline$G 20$ & NLLP_CPC_07-29 & $56.9^{\text {fghi }}$ & $88.3^{\mathrm{abcd}}$ & $70.8^{\text {edfg }}$ & $14.9^{\text {abcde }}$ & $10.9^{\text {bcde }}$ & $2201.0^{\mathrm{bcd}}$ & $11.3^{\text {bcdef }}$ \\
\hline$G 21$ & ACC 223402 & $56.3^{\mathrm{ijk}}$ & $87.0^{\text {bcdef }}$ & $81.4^{\mathrm{abc}}$ & $16.0^{\text {defgh }}$ & $11.2^{\mathrm{bcd}}$ & $2110.9^{\text {bcde }}$ & $10.2^{\mathrm{ghi}}$ \\
\hline G22 & NLLP_CPC_07_48B & $61.4^{\mathrm{a}}$ & $90.5^{\mathrm{a}}$ & $69.6^{\text {defg }}$ & $15.1^{\text {bcdefg }}$ & $10.6^{\text {cde }}$ & $2101.2^{\text {bcde }}$ & $10.4^{\mathrm{fgh}}$ \\
\hline$G 23$ & NLLP_CPC_07-03 & $59.7^{\mathrm{bc}}$ & $88.7^{\mathrm{abc}}$ & $74.4^{\text {cdef }}$ & $17.2^{\mathrm{defgh}}$ & $10.2^{\text {be }}$ & $2152.6^{\mathrm{bcd}}$ & $13.6^{\mathrm{a}}$ \\
\hline$G 24$ & NLLP_CPC 07-55 & $59.3^{\text {cde }}$ & $87.5^{\text {bcde }}$ & $76.2^{\text {bcd }}$ & $15.6^{\mathrm{abc}}$ & $11.5^{\mathrm{abc}}$ & $2573.2^{\mathrm{a}}$ & $12.2^{\mathrm{bc}}$ \\
\hline \multirow[t]{3}{*}{$G 25$} & Kanketi & $58.3^{\text {cdefg }}$ & $85.3^{\mathrm{efg}}$ & $75.2^{\text {bcde }}$ & $13.6^{\text {bcdefg }}$ & $11.1^{\mathrm{bcd}}$ & $2138.9^{\text {bcde }}$ & $11.2^{\text {cdefg }}$ \\
\hline & Mean & $58.3^{* *}$ & $86.9^{* *}$ & $72.7^{* *}$ & $15.4^{* *}$ & $11.0^{* *}$ & $1961.9^{* *}$ & $10.3^{* *}$ \\
\hline & $\mathrm{CV}(\%)$ & 3.3 & 3.7 & 13.6 & 15.3 & 12 & 11.2 & 12.3 \\
\hline
\end{tabular}

${ }^{* *}=$ significant at $P<0.01 ;{ }^{*}=$ significant at $P<0.05 ; \mathrm{CV}(\%)=$ coefficient of variation in percent.

TABLE 7: Joint regression analysis of variance (ER's model) for grain yield of 25 cowpea genotypes grown at six environments during the 2019 cropping season in Ethiopia.

\begin{tabular}{lccc}
\hline Source & Df & SS & MS \\
\hline Total & 149 & 508555146 & 3413121.8 \\
Genotypes & 24 & 9072930.8 & $378038.78^{* *}$ \\
Evn. + (gen $x$ env.) & 125 & 41782215 & $334257.7232^{* *}$ \\
Environment (linear) & 1 & 17321917 & $171125.69^{*}$ \\
Gen $x$ env. (Linear) & 24 & 4107016.6 & $203532.82^{* *}$ \\
Pooled deviation & 100 & 20353282 & $214204.30^{* *}$ \\
G1 & 4 & 856817.19 & $151748.78^{* *}$ \\
G2 & 4 & 606995.12 & $513100.62^{* *}$ \\
$G 3$ & 4 & 2052402.5 & $93309.11^{* *}$ \\
G4 & 4 & 373236.43 & $107295.39^{* *}$ \\
$G 5$ & 4 & 429181.56 & $114689.80^{* *}$ \\
$G 6$ & 4 & 458759.21 & $302211.30^{* *}$ \\
$G 7$ & 4 & 1208845.2 & $289734.82^{* *}$ \\
G8 & 4 & 1158939.3 & $263232.55^{* *}$ \\
G9 & 4 & 1052930.2 & $55436.105 \mathrm{~ns}$ \\
$G 10$ & 4 & 221744.42 & $341211.56^{* *}$ \\
$G 11$ & 4 & 1364846.2 & $163690.39^{* *}$ \\
$G 12$ & 4 & 654761.56 & $234905.78^{* *}$ \\
$G 13$ & 4 & 939623.1 & $38954.385 \mathrm{~ns}$ \\
$G 14$ & 4 & 155817.54 & $105502.41^{* *}$ \\
$G 15$ & 4 & 422009.65 & $244054.54^{* *}$ \\
$G 16$ & 4 & 976218.16 & $139241.38^{* *}$ \\
$G 17$ & 4 & 556965.53 & $440607.88^{* *}$ \\
\hline
\end{tabular}


TABLE 7: Continued.

\begin{tabular}{lccc}
\hline Source & Df & SS & MS \\
\hline$G 19$ & 4 & 1406098.2 & $351524.55^{* *}$ \\
$G 20$ & 4 & 342277.28 & $85569.32^{*}$ \\
$G 21$ & 4 & 67484.1 & $16871.025 \mathrm{~ns}^{*}$ \\
$G 22$ & 4 & 487173.65 & $121793.41^{* *}$ \\
$G 23$ & 4 & 1502497.6 & $375624.39^{* *}$ \\
$G 24$ & 4 & 337378.94 & $84344.735^{*}$ \\
$G 25$ (ch) & 4 & 957847.86 & $239461.97^{* *}$ \\
Pooled error & 300 & 7300322.8 & 24334.41 \\
\hline
\end{tabular}

**, * Significant at $P \leq 0.01$ and 0.05 , respectively, $\mathrm{Df}=$ degree of freedom; $\mathrm{SS}=$ sum of squares; $\mathrm{MS}=$ mean of squares, Env= environments, Gen = genotype.

TABLE 8: Stability parameters from Eberhart and Russell's models for grain yield across environments.

\begin{tabular}{|c|c|c|c|c|c|c|}
\hline Genotypes & Grain yield $\left(\mathrm{kg} \mathrm{ha}^{-1}\right)$ & Rank & $b_{i}$ & Rank & $\mathrm{S}^{2} \mathrm{di}$ & Rank \\
\hline$G 1$ & 2129.83 & 11 & $0.07 \mathrm{~ns}$ & 1 & $189869.89^{* *}$ & 14 \\
\hline$G 2$ & 2276.25 & 3 & $0.86 \mathrm{~ns}$ & 8 & $127414.38^{* *}$ & 12 \\
\hline G3 & 2021.01 & 16 & $0.71 \mathrm{~ns}$ & 7 & $488766.21^{* *}$ & 25 \\
\hline G4 & 2250.34 & 6 & $1.13 \mathrm{~ns}$ & 15 & $68974.70^{* *}$ & 6 \\
\hline G5 & 2078.41 & 12 & $1.76 *$ & 25 & $82960.98^{* *}$ & 8 \\
\hline G6 & 1883.44 & 19 & $1.73 *$ & 24 & $90355.39^{* *}$ & 9 \\
\hline G7 & 2263.27 & 5 & $1.09 \mathrm{~ns}$ & 13 & $277876.89^{* *}$ & 20 \\
\hline G8 & 1945.3 & 18 & $0.49 \mathrm{~ns}$ & 6 & $265400.41^{* *}$ & 19 \\
\hline G9 & 2040.57 & 15 & $1.11 \mathrm{~ns}$ & 14 & $238898.14^{* *}$ & 18 \\
\hline$G 10$ & 2046.15 & 14 & $1.56 *$ & 21 & $31101.69^{* *}$ & 3 \\
\hline$G 11$ & 1535.02 & 25 & $0.40 \mathrm{~ns}$ & 5 & $316877.15^{* *}$ & 21 \\
\hline$G 12$ & 1630.21 & 24 & $0.36 \mathrm{~ns}$ & 4 & $139355.98^{* *}$ & 13 \\
\hline G13 & 2053.39 & 13 & $1.48 \mathrm{~ns}$ & 20 & $210571.37^{* *}$ & 15 \\
\hline G14 & 1647 & 23 & $0.25 \mathrm{~ns}$ & 2 & $14619.98^{* *}$ & 2 \\
\hline G15 & 1824.91 & 21 & $1.58 *$ & 23 & $81168.00^{* *}$ & 7 \\
\hline G16 & 2290.41 & 2 & $0.99 \mathrm{~ns}$ & 11 & $219720.13^{* *}$ & 17 \\
\hline G17 & 1765.12 & 22 & $1.27 \mathrm{~ns}$ & 18 & $114906.97^{* *}$ & 11 \\
\hline$G 18$ & 1995.7 & 17 & $1.14 \mathrm{~ns}$ & 17 & $416273.48^{* *}$ & 24 \\
\hline G19 & 1837.86 & 20 & $1.04 \mathrm{~ns}$ & 12 & $327190.14^{* *}$ & 22 \\
\hline G20 & 2213.16 & 8 & $0.97 \mathrm{~ns}$ & 10 & $61234.91^{* *}$ & 5 \\
\hline$G 21$ & 2198.51 & 9 & $1.13 \mathrm{~ns}$ & 16 & $-7463.38 \mathrm{~ns}$ & 1 \\
\hline$G 22$ & 2161.01 & 10 & $0.28 \mathrm{~ns}$ & 3 & $97459.00^{* *}$ & 10 \\
\hline$G 23$ & 2242.47 & 7 & $1.57 *$ & 22 & $351289.98^{* *}$ & 23 \\
\hline G24 & 2632.42 & 1 & $0.91 \mathrm{~ns}$ & 9 & $60010.33^{* *}$ & 4 \\
\hline G25 (ch) & 2273.28 & 4 & $1.27 \mathrm{~ns}$ & 19 & $215127.56^{* *}$ & 16 \\
\hline
\end{tabular}

${ }^{* *}=$ significant at $P \leq 0.01,{ }^{*}=$ significant at $P \leq 0.05, \mathrm{~ns}=$ nonsignificant, $\mathrm{kg} \mathrm{ha}^{-1}=$ kilogram per hectare of pooled mean over six environments, $b_{i}$ and $\mathrm{S}^{2} \mathrm{di}$, regression coefficient and deviation from the regression, respectively.

Likewise, Nigussie [38] have reported that twelve out of fifteen common bean genotypes evaluated at six environments had $S^{2}$ di values significantly different from zero.

From the tested genotypes, 11 genotypes had lower grain yield than the grand mean of genotypes, which showed that these genotypes were not desirable for cultivation though they were stable. The most stable genotypes with the lowest $S^{2}$ di values were $G 21, G 14, G 10, G 24, G 20$, and G4, which ranked $1^{\text {st }}, 2^{\text {nd }}, 3^{\text {rd }}, 4^{\text {th }}, 5^{\text {th }}$, and $6^{\text {th }}$ for deviation from regression, respectively, from the lowest to highest. However, genotype G21 showed a nonsignificant deviation from regression and negative $S^{2}$ di value with lower grain yield, indicating its suitability for unfavourable environments. The most unstable genotypes with the highest $S^{2}$ di values were $G 19, G 23, G 18$, and $G 3$, which ranked $22^{\text {nd }}, 23^{\text {rd }}, 24^{\text {th }}$, and $25^{\text {th }}$ correspondingly among the tested genotypes. Therefore, these genotypes are best fit for specific adaptation in favourable environments where there are high input levels. If the mean yield, regression coefficient value $\left(b_{i}\right)$, and the deviation from the regression $\left(S^{2} \mathrm{di}\right)$ are considered together, then the most stable genotype would be $G 24$ with a mean grain yield of $2632 \mathrm{~kg} \mathrm{ha}^{-1}$ (ranked $1^{\text {st }}$ in yield), $9^{\text {th }}$ in regression coefficient $\left(b_{i}=0.91\right.$ close to 1$)$, and $4^{\text {th }}$ in deviation from the regression. Genotype $\mathrm{G} 2$ with a mean grain yield of $2276.23 \mathrm{~kg} \mathrm{ha}^{-1}$ and $G 20\left(2213.16 \mathrm{~kg} \mathrm{ha}^{-1}\right)$ would be the $2^{\text {nd }}$ and $3^{\text {rd }}$ most stable genotypes among the tested. Two genotypes (G5 and G23) among thirteen high yielder genotypes had a significant deviation of regression coefficient $\left(b_{\mathrm{i}}\right)$ values from unity, with a significant deviation of $S^{2}$ di value from zero $\left(S^{2} \mathrm{di}>0\right)$, indicating that they were unstable and desirable for cultivation in favourable environments. In agreement to this, Tariku [24] in cowpea and Firew [29], Abele [25], and Tullu [26] in common bean had identified the stable genotypes which are desirable for cultivation in all 
TABLE 9: Stability analysis using Wricke's ecovalence (Wi) and cultivar superiority measure $(\mathrm{Pi})$ of the Lin and Binns model.

\begin{tabular}{lcccccc}
\hline Genotypes & $\begin{array}{c}\text { Grain yield } \\
\left(\mathrm{kg} \mathrm{ha}^{-1}\right)\end{array}$ & Rank & Wi & Rank & Pi & Rank \\
\hline$G 1$ & 2130 & 11 & 1653466 & 22 & 439506 & 13 \\
$G 2$ & 2276 & 3 & 621011 & 8 & 255473 & 2 \\
$G 3$ & 2021 & 16 & 2110548 & 25 & 664236 & 19 \\
$G 4$ & 2250 & 6 & 384425 & 5 & 280255 & 3 \\
$G 5$ & 2078 & 12 & 827808 & 10 & 435876 & 12 \\
$G 6$ & 1883 & 19 & 827812 & 11 & 650874 & 18 \\
$G 7$ & 2263 & 5 & 1215161 & 18 & 320461 & 8 \\
$G 8$ & 1945 & 18 & 1337327 & 19 & 627385 & 17 \\
$G 9$ & 2041 & 15 & 1061949 & 15 & 528960 & 15 \\
$G 10$ & 2046 & 14 & 221842 & 2 & 415887 & 11 \\
$G 11$ & 1535 & 25 & 1617493 & 21 & 1126704 & 25 \\
$G 12$ & 1630 & 24 & 940800 & 13 & 887791 & 24 \\
$G 13$ & 2053 & 13 & 1097987 & 16 & 474959 & 14 \\
$G 14$ & 1647 & 23 & 545296 & 6 & 850599 & 23 \\
$G 15$ & 1825 & 21 & 656522 & 9 & 709147 & 22 \\
$G 16$ & 2290 & 2 & 1197791 & 17 & 296859 & 5 \\
$G 17$ & 1765 & 22 & 605750 & 7 & 702671 & 21 \\
$G 18$ & 1996 & 17 & 1776428 & 24 & 586899 & 16 \\
$G 19$ & 1838 & 20 & 1407161 & 20 & 697557 & 20 \\
$G 20$ & 2213 & 8 & 342873 & 3 & 301445 & 6 \\
$G 21$ & 2199 & 9 & 79422 & 1 & 290328 & 4 \\
$G 22$ & 2161 & 10 & 849857 & 12 & 360932 & 9 \\
$G 23$ & 2242 & 7 & 1729884 & 23 & 410594 & 10 \\
$G 24$ & 2632 & 1 & 343227 & 4 & 63329 & 1 \\
$G 25$ & 2273 & 4 & 1008432 & 14 & 306404 & 7 \\
\hline & & & & & &
\end{tabular}

tested environments by using high mean grain yield, nonsignificant regression coefficient from unity, and nonsignificant deviation from regression values $\left(S^{2} \mathrm{di}=0\right)$.

3.4. Stability Analysis Using Wricke's Ecovalence (Wi) and Cultivar Superiority Measure (Pi) of the Lin and Binns Model. Wricke [39] defined the concept of ecovalence, to describe the stability of a genotype as the contribution of each genotype to the genotype $x$ environment interaction sum of squares. The ecovalence $(\mathrm{Wi})$ or the stability of the $i^{\text {th }}$ genotype is its interaction with environments, squared and summed across environments. According to this model, genotypes with low ecovalence have smaller fluctuations across environments and contributed the least to the genotype by environment interaction and, thus, are stable genotypes. The analysis in Table 9 showed that G21, G10, G20, G24, G4, and G14 were the most stable genotypes that ranked $9^{\text {th }}, 14^{\text {th }}, 8^{\text {th }}, 1^{\text {st }}, 6^{\text {th }}$, and $23^{\text {rd }}$, for grain yield, respectively. In harmony to this, Ishiyaku et al. [23] in cowpea and Tadele et al. [30] in common bean had reported the highest yielder genotypes having relatively low ecovalence values. The most unstable genotypes according to the ecovalence method were $G 3, G 18, G 23$, and $G 1$, showing relatively higher ecovalence \% of GXE sum squares for grain yield, and ranked $16^{\text {th }}, 17^{\text {th }}, 7^{\text {th }}$, and $11^{\text {st }}$ in mean grain yield, respectively. According to Asrat et al. [40], genotypes with high ecovalence mean and large estimated values are suitable for high-input environments.
As a stability statistic, the cultivar performance measure (Pi) of Lin and Binns [41] is estimated by the square of differences between a genotype's and the maximum genotype mean at a location, summed and divided by twice the number of locations. The most stable genotype is the one with the least deviation from the maximum yield of each environment, i.e., with the lowest (Pi) value. From the present investigation, the most stable genotype ranked first for $\mathrm{Pi}$ and for mean grain yield was G24 followed by $G 2, G 4, G 21$, and G16, respectively (Table 9). These stable genotypes had the least contribution to the total variation due to the genotype by environment interaction. In contrast, G11, G12, G14, and $G 15$ were the most unstable genotypes, and they contributed a large portion of the total variation due to GEI. These results are in agreement with the work of Alemayehu et al. (2016), and Tadele et al. [30], who reported the most stable cowpea genotypes having the lowest $\mathrm{Pi}$ value and high mean grain yield in their study.

\section{Conclusions and Recommendation}

Analysis of variance for each location and combined over five locations showed significant differences among genotypes, environments, and genotypes $\times$ environments interaction (GEI) for grain yield and most of the yieldrelated traits. The significant genotypes $\times$ environments interaction effects indicated the inconsistent performance of genotypes across the tested environments and the differential discriminating ability of the tested environments.

Among the tested environments, the highest mean grain yield $\left(2529 \mathrm{~kg} \mathrm{ha}^{-1}\right)$ was registered at Miesso followed by Melkassa $\left(2487 \mathrm{~kg} \mathrm{ha}^{-1}\right)$, while Sirinka $\left(1676 \mathrm{~kg} \mathrm{ha}^{-1}\right)$ and Babile $\left(1730 \mathrm{~kg} \mathrm{ha}^{-1}\right)$ were the least-yielding environments. The highest grain yield was obtained from NLLP_CPC_07$55\left(2632.4 \mathrm{~kg} \mathrm{ha}^{-1}\right)$, ACC233403 (2290.4 $\left.\mathrm{kg} \mathrm{ha}^{-1}\right)$, and NLLP_CPC_07-74 $\left(2276.3 \mathrm{~kg} \mathrm{ha}^{-1}\right)$. These three genotypes gave mean grain yield above the standard check Kanketi among the tested genotypes. The lowest mean grain yield was registered from ACC222890 (1535.0 kg ha $\left.{ }^{-1}\right)$, Dass 002 $\left(1630.2 \mathrm{~kg} \mathrm{ha}^{-1}\right)$, and NLLP_CPC_07-69 $\left(1647.0 \mathrm{~kg} \mathrm{ha}^{-1}\right)$.

The significant effects of GEI on traits suggested the need to assess the stability of genotypes overall environments. The stability of 25 cowpea genotypes for grain yield over six environments was estimated by using cultivar superiority $(\mathrm{Pi})$, Wricke's ecovalence (Wi), regression coefficient $\left(b_{i}\right)$, and devotion from regression $\left(\mathrm{S}^{2} \mathrm{di}\right)$ models. Among the tested genotypes, NLLP_CPC_07-55 $\left(2632 \mathrm{~kg} \mathrm{ha}{ }^{-1}\right), \quad$ NLLP_CPC_07-74 $\left(2276 \mathrm{~kg} \mathrm{ha}^{-1}\right)$, NLLP_CPC_07-27 (2250 kg ha $\left.{ }^{-1}\right)$, NLLP_CPC_07-29 $\left(2213 \mathrm{~kg} \mathrm{ha}^{-1}\right)$, and ACC $233403\left(2290 \mathrm{~kg} \mathrm{ha}^{-1}\right)$ were most stable genotypes without a statistically significant difference in mean grain yield; however, only the first three genotypes exceed the standard check variety Kanketi in grain yield. Therefore, these genotypes have been identified as a candidate to release for wider adaptation and commercial production. 


\section{Data Availability}

The data that support the findings of this study are openly available in Yirga at https://www. researchgate.net/profile/ Yirga_Wasihun.

\section{Conflicts of Interest}

The authors declare no conflicts of interest on submission of this manuscript.

\section{Acknowledgments}

First of all, the authors would like to express their special gratitude and deepest thanks to pulse crop breeders, Mr. Eyeberu Abera, Mr. Abele Moges, and Mrs. Dagmawit Tsegaye, from Sirinka and Mellkassa Agricultural Research Centers, respectively, for their unlimited assistance in handling the field Experiment and data collection. Also, the authors do not want to pass without thanking Dr. Wassu Mohammed from Haramaya University for his academic support on stability analysis using SPAR 2.0 software. Secondly, they acknowledge the Melkassa Agricultural Research Center for providing experimental materials and testing fields and Srinka Agricultural Research Center and Haramaya University for providing testing fields. Finally, their deepest gratefulness goes to the Sekota Dryland Agricultural Research Center under Amhara Regional Agricultural Research Institute for granting them this opportunity and financial support.

\section{References}

[1] F. O. Ogbemudia, E. M. Denise, E. A. Ogie-Odia, and A. C. Omonhinmin, "Comparative germination studies of cowpea (vigna ungiculata L. Walp.) and soybean (Glycine max L. Merr.) on whole and water saturated fractions of hydrocarbon (hexane)," Annals of Biological Research, vol. 1, no. 4, pp. 34-40, 2010.

[2] OECD (Organisation for Economic Co-operation and Development), "Consensus document on the biology of cowpea (vigna unguiculata (L.) walp.)," ENV/JM/MONO, vol. 48, no. 60, 2015.

[3] S. Hill, "Cowpea adaptability to southeastern organic farming systems : forage productivity and charcoal rot susceptibility," MSc. Thesis, University of Tennessee, Knoxville, Tennessee, 2015.

[4] J. B. Noubissietchiagm, J. M. Bell, S. Guissaibirwe, S. Gonne, and E. Youmbi, "Varietal response of cowpea ( vigna unguiculata L. Walp.) to striga gesnerioides (wild.) vatke race SG5 infestation," Horti Agrobotanici, Cluj-Napoca, vol. 38, no. 2, pp. 33-41, 2010.

[5] P. K. Baidoo and M. B. Mochiah, "Varietal susceptibility of improved cowpea vigna unguiculata (L.) (walp.) cultivars to field and storage pests," Sustainable Agriculture Research, vol. 3, no. 2, p. 69, 2014.

[6] T. Abate, A. D. Alene, D. Bergvinson, S. Silim, A. Orr, and S. Asfaw, "Tropical legumes in Africa and South Asia: knowledge and opportunities," TL II Research Report No. 1, ICRISAT, Nairobi, Kenya, 2011.

[7] B. B. Singh, J. D. Ehlers, B. Sharma, and F. R. Freire, "Recent progress in cowpea breeding," in Challenges and
Opportunities for Enhancing Sustainable Cowpea Production, CA. Fatokun, SA. Tarawali, BB. Singh, PM. Kormawa, and M. Tamo, Eds., IITA, Ibada Nigeria, 2002.

[8] A. Mulugeta, Z. Asefaw, Z. Woldu, B. Amsalu, and B. Medvecky, "Cowpea (vigna unguiculata ( L.) walp.) (Fabaceae ) landrace diversity in northern Ethiopia," International Journal of Biodiversity and Conservation, vol. 8, no. 11, pp. 297-309, 2017.

[9] S. Alemu, "Cowpea (Vigna Unguiculata (L.) Walp.) (Fabaceae) landrace diversity in Southern Ethiopia," MSc. Thesis, Addis Ababa University, Addis Ababa, Ethiopia, 2015.

[10] E. Sariah John, Enhancing cowpea (vigna unguiculata L.) Production through insect pest resistant line in East Africa, $\mathrm{PhD}$ Thesis, University of Copenhagen, Copenhagen, Denmark, 2010.

[11] M. P. Timko and B. B. Singh, "Cowpea, a multifunctional legume," in Genomics of Tropical Crop Plants, P. H. More and R. Ming, Eds., pp. 227-257, Springer, New York, NY, USA, 2008.

[12] Fonji Atemkengn koumki Maureen, Genetic analysis of traits related to biological nitrogen fixation in cowpea [vigna unguiculata L.WALP] under low soil phosphorus, $\mathrm{PhD}$ Thesis, University of Ghana, Legonm, Ghana, 2015.

[13] L. Horn, H. Shimelis, and M. Laing, "Participatory appraisal of production constraints, preferred traits and farming system of cowpea in the northern Namibia: implications for breeding," Legume Research, vol. 38, no. 5, pp. 691-700, 2015.

[14] B. D. Adewale, O. Adeigbe, and C. Aremu, "Genetic distance and diversity among some cowpea (vigna unguiculata L. Walp) genotypes," International Journal of Research in Pharmacy and Science, vol. 1, no. 2, pp. 9-14, 2011.

[15] A. E. Hall, N. Cisse, S. Thiaw et al., "Development of cowpea cultivars and germplasm by the bean/cowpea CRSP," Field Crops Research, vol. 82, no. 2-3, pp. 103-134, 2003.

[16] H. Gauch and W. Zobel, "AMMI analysis of yield trials," in Genotypes by Environment Interaction, S. Kang and H. Gauch, Eds., CRC, New York, NY, USA, 1996.

[17] M. Bandeira, K. Jackson, M. de Moura, J. Angelo, and L. Raphaelle, "Genotype by environment interaction in cowpea lines using GGE biplot method," Universidade Federal Rural do Semi-Árido, vol. 31, no. 1, pp. 64-71, 2018.

[18] SAS ( Statistical Analysis System) Software, Version 9.2, Inc. Carth Carolina, Cary, NC, USA, 2009.

[19] GenStat Release 18th Edition ( PC/windows 10) Copyright. 2015. VSN International Ltd. Germplasm.

[20] H. O. Hartley, "The maximum F-ratio as a short cut test for heterogeneity of variances," Biometrika, vol. 37, no. 3-4, pp. 308-312, 1950.

[21] S. A. Eberhart and W. A. Russell, "Stability parameters for comparing varieties 1," Crop Science, vol. 6, no. 1, pp. 36-40, 1966.

[22] A. Santos, G. Ceccon, E. V. Rodrigues et al., "Adaptability and stability of cowpea genotypes to Brazilian midwest," African Journal of Agricultural Research, vol. 10, no. 41, pp. 3901-3908, 2015.

[23] I. Mohammed, M. Y. Victoria, BB. Singh, O. Olufajo, and A. A. Zaria, "Phenotypic stability for selected traits of some cowpea lines in Nigerian agro-ecologies," Plant Biology and Biotechnology, vol. 5, no. 2, pp. 67-77, 2017.

[24] T. Simion, "Genotype by environment interaction and stability analysis in Cowpea [Vigna Unquiculata (L.) Walp] genotypes for yield in Ethiopia," MSc. Thesis, Haramaya University, Haramaya, Ethiopia, 2017.

[25] A. Moges, "Genotype by environment interaction on yield and micronutrient concentration of biofortified common 
bean (Phaseolus vulgaris L.) in Ethiopia," MSc Thesis, Haramaya University, Haramaya, Ethiopia, 2017.

[26] T. A. Tullu, "Genotype X environment interaction for agronomic traits and yield stability of common bean (phaseolus vulgaris L.) varieties in hararghe, eastern Ethiopia," MSc. Thesis, Haramaya Univesity, Haramaya, Ethiopia, 2018.

[27] K. A. Gomez and A. A. Gomez, Statistical Procedure for Agricultural Research, 2nd ed., John Wiley and Sons, New York, NY, USA, 1984.

[28] A. A. H. El Shaieny, Y. A. A. Abdel-Ati, M. E. D. El-Damarany, and M. R. Rashwan, "Stability analysis of components characters in cowpea (Vigna unguiculata (L.) Walp)," Journal of Horticulture and Forestry, vol. 7, no. 2, pp. 24-35, 2015.

[29] F. Mekibib, "Simultaneous selection for high yield and stability in common bean (Phaseolus vulgaris) genotypes," The Journal of Agricultural Science, vol. 138, no. 3, pp. 249-253, 2002.

[30] T. Tadesse, G. Sefera, B. Asmare, and A. Teklaign, "Application of AMMI for grain yield stability analysis in large speckled bean genotypes grown in midlands of bale zone," Chemical and Biomolecular Engineering, vol. 3, no. 3, pp. 17-21, 2018.

[31] H. N. Pham and M. S. Kang, "Interrelationships among and repeatability of several stability statistics estimated from international maize trials," Crop Science, vol. 28, no. 6, pp. 925-928, 1988.

[32] W. Yan and M. S. Kang, "GGE Biplot Analysis: a graphical tool for breeders," in Geneticists, and Agronomist, M. S. Kang, Ed., pp. 63-88, CRC Press, Boca Raton, FL, USA, 2003.

[33] C. Sarvamangala, M. S. Uma, S. Birada, and P. M. Salimath, "Stability analysis for yield and yield components over seasons in cowpea (vigna unguiculata L. Walp)," Electronic Journal of Plant Breeding, vol. 1, no. 6, pp. 1392-1395, 2010.

[34] H. Nunes, F. Rodrigues Freire Filho, V. Q. Ribeiro, and R. L. Ferreira Gomes, "Grain yield adaptability and stability of blackeyed cowpea genotypes under rainfed agriculture in Brazil," African Journal of Agricultural Research, vol. 9, no. 2, pp. 255-261, 2014.

[35] K. Finlay and G. Wilkinson, "The analysis of adaptation in a plant-breeding programme," Australian Journal of Agricultural Research, vol. 14, no. 6, pp. 742-754, 1963.

[36] M. Rodriguez, D. Rau, R. Papa, and G. Attene, "Genotype by environment interactions in barley (Hordeum vulgare L.): different responses of landraces, recombinant inbred lines and varieties to Mediterranean environment," Euphytica, vol. 163, no. 2, pp. 231-247, 2007.

[37] B. D. Adewale, C. Okonji, A. Oyekanmi, D. Akintobi, and C. O. Aremu, "Genotypic variability and stability of some grain yield components of cowpea," African Journal of Agricultural Research, vol. 5, no. 9, pp. 874-880, 2010.

[38] N. Kefelegn, "Genotype x environment interaction of released common bean (Phaseolus vulgaris L.) varieties," MSc. Thesis, Haramaya University, Haramaya, Ethiopia, 2012.

[39] G. Wricke's, "Ubereine method zur erfassung der okologischen streuberite in feldversuchenz," Pflanzerzuentz, vol. 47, pp. 92-96, 1962.

[40] A. Asrat, T. Assefa, B. Amsalu et al., "Adaptation and yield stability of small red beans elite lines in Ethiopia," International Journal of Plant Breeding and Genetics, vol. 2, no. 2, pp. 51-63, 2008.

[41] C. S. Lin and M. R. Binns, "A superiority measure of cultivar performance for cultivar x location data," Canadian Journal of Plant Science, vol. 68, no. 1, pp. 93-198, 1988. 